\title{
めん羊の陰囊にお淤る象皮病様 疾患とへルニアの治験
}

\author{
甲斐田凹郎* 鐘厅汇 進*

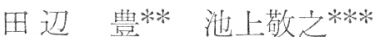

当地方化和けるめん羊の疾病以腰麻瘦力゙最も多く，消 化器病と皮膚病がこ机につぎ，生殖器病はまったくその 例劣見ない。成書にもこれについての記載はなされてい ないようである。

しかるにわれわれははからずもこのたびめん羊の陰囊 の疾病 2 例に遭遇したのでんの概略を䞢告し，大方の参 考汇資することとする。

\section{1. 陰震象皮病について}

め九羊, 雄, 4才, メリノ一雑, 福自県産 福葥県浮 羽郡田主丸町竹野地区大㦄寺 ○本○次郎所有

1）経歴：約 2 年前㴡島県より移入したるもので， 現在末で病歴はない

2) 目告：約 3 力月前より次第飞㓌囊が腫れあがり， これに伴うて栄盖も衰光起卧困難となった。

3) 現症：昭利 32 年 8 月 2 日初猃与る, 元気, 食 欲とも江衰完，被毛光沢なく，栄看はなはだしく衰完， 起卧むまた困難で，歩行踰踉として李ったく元気がな い.

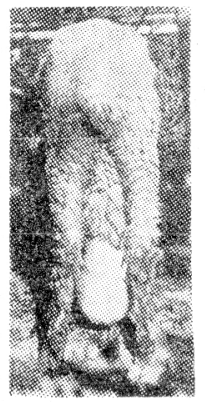

(1) 手術正前
有院囊はとくに異常を認めないが， 左陰囊は著しく腄脹し，父の長さ約48 $\mathrm{cm}$ ，最大周井 $40 \mathrm{~cm}$ の出たか子一升び 几状の感表旺し，運歩每汇大きく前後

\section{めん羊の陰賈象皮病患}

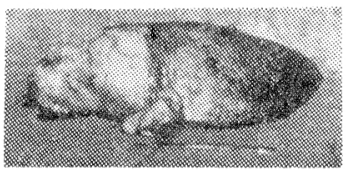

（2）切除した陰賈病変部（左方が附着部）

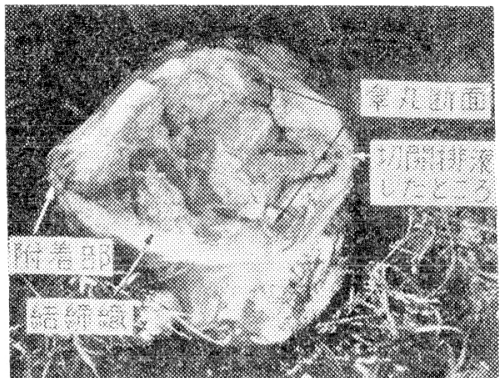

(3) 病変部の断面

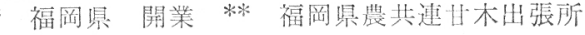
*** 福岡買浮羽家畜保健符生所
左右にゆれ，ほとえど先の尖端は接地しそうで出る。触

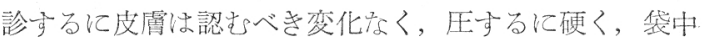
の石に触るような感じがある。腫脹部を試みに穿刺する に淡黄色透明の漿液約100ccを索採集した。

4）処置 : 注射針にて排液処置を2 回行ったが無效な ので，腫脹部の最下底部孝約 $5 \mathrm{~cm}$ 切開し排液学はかり， その後 2 週間観察したが，まったく治癒の見边多がない ので，観血手街学尖施した。

すなわち，腫大せる陰囊の附着部より下方約 $2 \mathrm{~cm} の$ 部

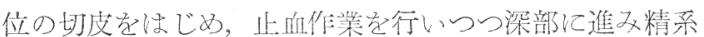
学取り出し，絹糸で結禁し，挫切錟を以て一気に切除 し，綿密比血したのち度膚縫合を行いヨードチンキを 塗布与る。な扮破賃風血清5 cc 学皮下注射した。

5）予後执よび経過：手很後一般状態は良好で，10日 後には元気，食欲ともに旧復し，1力月後には素った く回復し，栄養状態も良好となった。手術創も幸にして 第 1 期癒合した。

6）病変部の所見：手術により切除した病恋部は，長 巳 $48 \mathrm{~cm}$, 周囲 $40 \mathrm{~cm}$ の長㤢円形を呈し, 肉眼的に皮膚の

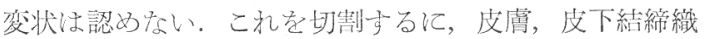
特よび夾膜などの識别因難で合の厚さ約 $5 \mathrm{~cm}$ あり，全 面的に結締織の增殖を認め, 内部 (中心部) は細唇い空

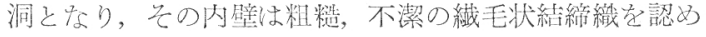
た。

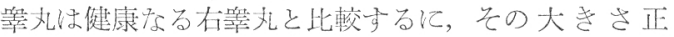
常，実質もまた肉腿的に罳常を認めず，增殖したる結締 織内に埋没されたごとき状態で, 腫脹病変部下 $1 / 3$ の女 たりにあった

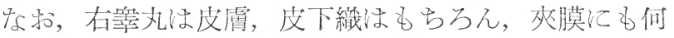
ら認导べき変状なく，腫大した陰囊の右側正常位に出っ た。

7）診断検査：この現症および経過より一伈フィラリ アの子出に起因与る象皮病老疑い，患部の漿液亚びに血 液について 3 日間隔で 3 回，とくに血液㲹ついては夜 9 １0時頃飞も採血（3日間隔 3 回）検查した．

すなわら，(1)血液和よび漿液をとのまま検查，(2)四検 材料（血液漿液）栄強力遠心器にて集虫検査，(3)（1)(2) の材料より塗抹椣本起造りギムザ染色後検查圭した，

上記のごとく检查学实施したが，いずれもフィラリア

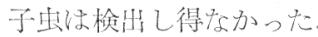

\section{2. 陰囊へルニアについて}

め九羊，焳，5才火リノ一雑，福皇県産 福阊県浮羽 郡吉井町福富地区 小○倿○所有

1) 経歴：4 年前，福皇県より移入したるもので今日 まで病気にかかったことがない。

2) 禀告: 約 $1 \sim 2$ 力月前より, 陰霆がやや腫れてい 


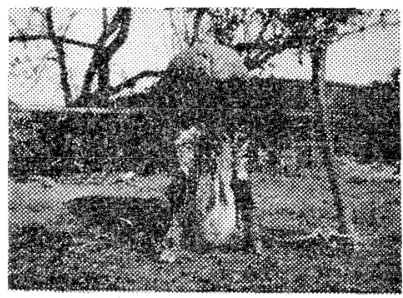

(1) 後 方 めん羊の陰囊へルニア

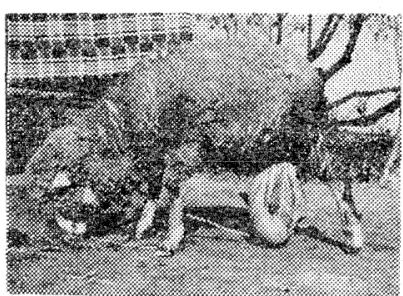

(2) 㑡 面

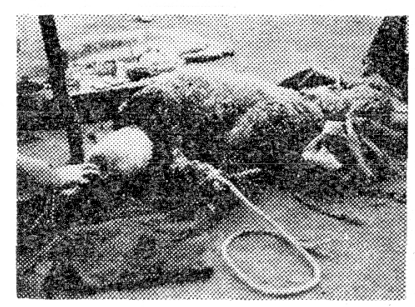

(3)手街直前
るの学見たが，食欲，その他に翼常がないので，そのま 柰放置していなが，近頃急に腫脤が加わり地に引げるよ らになった。一方策餋も次第に衰完てきたので受骖す る.

3) 現症: 栄養不良で, 元気, 食欲とも变化はない

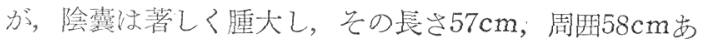
って奇観杂呈文る。

4) 骖断：患部の触診执よび武験穿刺により陰囊へル ニアと䛦断する.

5）妈置：患畜は頭低，尾䯩になるように仰卧せしめ 両後肢学左右已開いて保定し, 助手をして, 前肢, 頭部 の保定芫行为しめた。

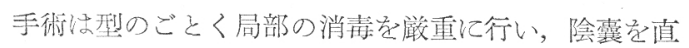
上に保持し，その腫脤部の最尖端を切開して手を㨂入検

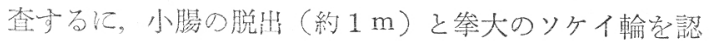

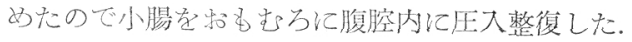

再脱出防止のためソケイ輸飞手をあて，一方助手をし て陰囊附着部の外ソケイ翰に近い部分の皮膚学切開し て, 精系学取り出しこれ学絽禁切除後, 精系の断端はこ

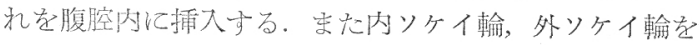
それぞれ縫合し，腫脹した㓌囊はとの附着部より切除 し，連続縫合を行ったのち，ヨードチンキを塗布する。 ※た破傷風血清5 c c 学皮下注射した。

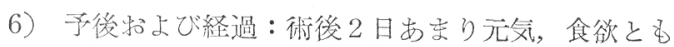
に衰光たが日增しに回復し，手術局部も源とえぞ腫脤を みず第 1 期癒合した。

\section{考察特よび結言}

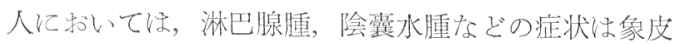
病の固有症状で出り，その原因は主としてバンクロフト 糸状虫で, これに夜間出現する夜間性糸状虫と昼間認め られる昼間性糸状虫との 2 型があり，鹿児島，熊本，長 崎の各県は象皮病の濃厚な地方とされている。

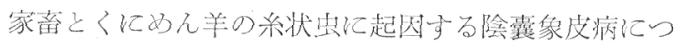

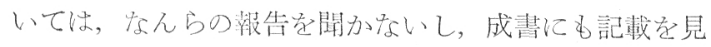
ないようである。

しかるに，われわれははからずもめん羊の陰囊象皮病 様疾患汇遭遇したのでここに先の概略走報告する次第
である。

すなわち，㓌囊腫脹病变部の肉眼的所見江括いて，皮

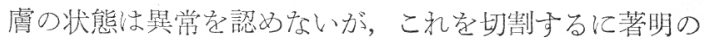
皮下結締組織の增成怘きたし(厚さ䄪 $5 \mathrm{~cm}$ )，ために支 䖉，皮下織ならびに夾膜との識別まったく不可能とな り，中心部は筀洞となって，その内壁は不潔粗雑なる繊 毛状結締組織にて包委れ，切開排液後の活染による化膿 が認みられた。

な扮等丸は正常の大きさで增殖した結締織のなかに包 埋され, 実質の萎縮, 硬度无の他, 間結締織の普殖など の変状は認められない。

以上のよ5な所見からして，われわ机は本症学一忘象 皮病ならずやと思考し, 病变腫脹部の呀刺により採集し た，透明なる淡黄色漿液について 3 日間隔で 3 回，また 血液については，耳静脈打よび頸静脈よりそれぞれ採血

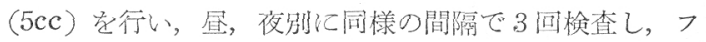
イラリア子虫の検出に努力したが，いずれもフィラリア 子虫学罗することができなかった。

また器珹的刺激作朋汇より陰囊水腫を発し, 長い期間 の放任のため獎液の刺激により二次的に皮下結締織の増 殖を起し，象皮病をみたのではないかとも思孝されるの で，陰囊皮覤を詳細に検査するもまったく健康で摖過傷 らしききずあともないし，畜主も莘丸の賃を受けたこと 学知らないるいらし，これの原因についてはまったく不 明である。そこで現症所見よりして，「陰囊水腫」より 「象皮病」といった方が適切かとも思考されたので，出 壳て「象皮病」とした。

第2 例の陰囊へルニア症について惊, 李ったくの初め てで，とくにめん羊がこれほど激しい脱腸（約１ｍ）圭 起して，活とえど無症状であった事整は警く泀どであ 万.

すなわ台内，外ソタイ翰が異常(拳大) に大きかった がために，疝痛症状や，食欲などの全身症状にまったく 異常が認められず，ただ㓌囊のゆるす最大限比小腸が脱 出し，あたか子両後肢間に一升德利袁つるしたよらな奇 钼を是したるのと思孝される。

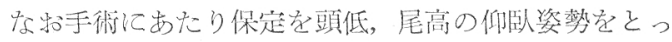
えことは，脱腸の整復汇好都合であった。

\section{日獣会裾 12 (1959)}

